\title{
KARAKTERISTIK PETERNAK DAN STRATEGI PENGEMBANGAN TERNAK KERBAU GAYO SISTEM PERUWEREN
}

\author{
(Livestock Characteristics and Strategy Development of Gayo Buffalo in the Peruweren \\ System)
}

\author{
Rusli $^{1}$ dan Syahidin ${ }^{2}$ \\ ${ }^{1}$ Fakultas Pertanian Universitas Gajah Putih, Takengo, Aceh Tengah, Aceh, 4560 \\ ${ }^{2}$ Fakultas Ekonomi Universitas Gajah Putih, Takengo, Aceh Tengah, Aceh, 4560 \\ Email: ruslilumut@gmail.com
}

\begin{abstract}
The purpose of this study was to determine the characteristics of breeders and the formulation of strategies for the development of the Gayo Buffalo cattle in Linge District, Central Aceh Regency. This research method uses a survey method, then analyzed using a SWOT analysis (strength, weakness, opportunity and threat). Respondents were 54 Gayo buffalo breeders who were determined purposively. The results of this study were the characteristics of breeders in Linge District, namely education, livestock ownership and knowledge of breeders which were still very low. As for the age, they are still very productive and have high motivation in raising Gayo Buffalo cattle in Linge District, Central Aceh Regency. Based on the weighted value of the grand strategy, an aggressive strategy is obtained, namely using empty land to be used as a source of feed and processed feed as well as increasing livestock population and production through improved management of maintenance, feed, and health by implementing the Artificial Insemination (AI) system.
\end{abstract}

Keywords: Buffalo Gayo, Development Strategy, Farmer Characteristics

\section{ABSTRAK}

Tujuan penelitian ini yaitu mengetahui kerakteristik peternak serta perumusan strategi pengembangan ternak Kerbau Gayo di Kecamatan Linge Kabupaten Aceh Tengah. metode penelitian ini menggunakan metede survey, kemudian dianalisis menggunakan Analisis SWOT (strength, weakness, opportunity dan threath). Responden adalah 54 peternak Kerbau Gayo yang ditentukan secara purposive. Hasil penelitian ini yaitu Karakteristik peternak di Kecamatan Linge yaitu pendidikan, kepemilikan ternak dan pengetahuan peternak masih sangat rendah. Sedangkan untuk umur masih sangat produktif dan memiliki motivasi yang tinggi dalam memelihara ternak Kerbau Gayo di Kecamatan Linge Kabupaten Aceh Tengah. Berdasarkana nilai pembobotan asil grand strategi maka diperoleh strategi Agresif yaitu Memanfaatkan lahan kosong untuk dijadikan sumber pakan dan pakan olahan serta meningkatkan populasi dan produksi ternak melalui perbaikan manajemen pemeliharaan, pakan, dan kesehatan dengan menerapkan sistem Inseminasi Buatan ((IB).

Kata Kunci : Kerbau Gayo, Strategi Pengembangan, Karaktersistik Peternak.

\section{PENDAHULUAN}

Kecamatan Linge merupakan salah satu kecamatan yang ada di Kabupaten Aceh Tengah yang memiliki luas $2.075 .28 \mathrm{~km}^{2}$ atau menguasai sekitar 48,06\% dari luas total Kabupaten Aceh Tengah. Kecamatan Linge juga salah satu daerah sentral peternakan di Kabupaten Aceh Tengah. adapun populasi tertinggi saat ini adalah ternak Kerbau Gayo sebanyak 13047 ekor, Kecamatan Linge memiliki populasi tertinggi yaitu 6.820 ekor dan sisanya tersebar di 13 kecamatan lainnya BPS (2020).

Kerbau Gayo salah satu ternak besar yang sudah di tetapkan di Kabupaten Aceh Tengah melalui keputusan Menteri Pertanian RI, Nomor: 302/Kpts/SR. 120/5/2017 tanggal 4 Mei 2017 sebagai kekayaan sumber daya genetik ternak lokal Indonesia. Pemeliharaan ternak kerbau Gayo itu sendiri masih diusahakan oleh peternak sebagai usaha sampingan yang diperlihara secara tradisional. Sistem itu udah 
dilakukan sejak nenek moyang mereka yang diwarisi secara turun temurun, dimana ternak dilepaskan di lahan yang sudah dibiasakan semenjak ternak itu ada, dan menjadi lokasi pemeliharaan peternak. Sumber pakan yang diperoleh masih mengandalkan pakan alami yang hidup dialam dan sangat jarang peternak menanam hijauan cadangan pakan ternak secara kontinyu. Sistem pemeliharaan seperti ini peternak jarang memperhatikan kesehatan ternak, masih menggunakan kawin alam serta tidak memanfaatkan recording dengan baik sehingga peningkatan populasi ternak kerbau belum signifikan (Par, 2018). Menurut Rusdiana and Herdiawan (2017), siklus produksi ternak kerbau terjadi sebagai akibat kurangnya efisiensinya faktor teknis produksi dan reproduksi terutama pada pemberian pakan dan cara pemeliharaannya.

Kerbau Gayo sampai saat ini belum diketahui secara pasti asal mula perkembangannya. Menurut Sari (2020) kerbau Gayo kemungkinan berasal dari daerah pesisir Aceh dan menyebar di daratan. Seiring dengan perkembangan penduduk dan tidak lagi serupa dengan aslinya akibat berkembang biak secara inbreending, diperkirakan sudah sejak abad ke19. Menurut hasil uji yang dilakukan oleh Sari (2015) kemudian Rusdiana and Herdiawan (2017) menyimpulkan ternak Kerbau Gayo secara genetika termasuk tipe kerbau lumpur dan belum terkontamisi dengan gen ternak kerbau lainnya yang telah diuji elektroforesis dan sekuensing DNA Kerbau Gayo.

Peternakan kerbau Gayo di Kecamatan Linge masih dilakukan dalam skala kecil yang bersifat sampingan dan sudah sejak lama dikembangkan bersama Sapi Aceh, jauh sebelum sapi Bali masuk ke Kecamatan Linge. Pemiliharaan ternak kerbau Gayo diusahakan oleh petani sejak puluhan tahun lalu. Peternakan menjadi andalan para peternak untuk memenuhi kebutuhan perekonomian keluarga seperti pendidikan, fasilitas keluarga, serta kebutuhan lainnya. Berbagai jenis ternak yang dikembangkan, namun yang cukup prospektif untuk dikembangkan adalah ternak kerbau, karena lebih mudah dipelihara dan tidak mudah menjadi liar, dalam sistem pemeliharaan tradisional serta ketersediaan lahan pengembalaan yang cukup luas untuk pengembalaan dan sumber makanan untuk ternak.

Sistem budidaya pemeliharaan seperti ini dikenal dengan "Peruweren", Sari (2020) peternak hanya sedikit meluangkan waktu dengan ternaknya serta penggunaan biaya yang sangat rendah. Lokasi pemeliharaan atau disebut lokasi peruweren oleh peternak kerbau Gayo cukup jauh dari perumahan peternak. Peternak membiarkan dan mengembalakan ternaknya pergi begitu saja sehingga, ternak sering masuk pada lokasi pertanian. Meskipun pada umumnya didaerah ini para petani memberikan pagar untuk lokasi pertaniannya, terkadang peternak harus mengganti rugi tanaman milik masyarakat akibat sudah dirusak oleh ternaknya. Hal ini sudah menjadi kebiasaan peternak terkadang banyak konfik yang terjadi akibat pemeliharaan ternak dilepaskan begitu saja. Memelihara ternak orang lain dengan sistem bagi hasil adalah salah satu cara peternak untuk mendapatkan modal awal ternak kerbau Gayo, sehingga populasi ternak kerbau Gayo berkembang cukup lamban. Faktor yang sangat mempengaruhi pengembangan ternak kerbau yaitu, karakteristik peternak, kondisi lingkungan, dan sistem manajemen yang memiliki korelasi tinggi rendahnya populasi ternak kerbau (Ikun, 2018).

Pada dasarnya ternak kerbau merupakan sumber daging yang disukai oleh banyak kalangan di Aceh Tengah sebagai tolak ukur kematangan ekonomi masyarakat baik secara sosial maupun dalam adat budaya masyarakat Aceh Tengah dan biasa dipotong saat acara megah dan sebagai hewan qurban karena ternak kerbau Gayo memiliki berat tubuh 8001200 kg (Sari, 2020). Menurut Yurleni (2013) kualitas daging kerbau lebih empuk dan dibandingan dengan daging sapi penyebaran lemak di antara serat daging yang lebih baik, serta serat daging yang lebih besar. Namun, persentase karkas kerbau lebih rendah yaitu 46,5 - 52,1\% dengan bobot karkas hampir sama yaitu $146,6-151,1 \mathrm{~kg}$.

Selain daging, ternak kerbau juga memproduksi susu yang dapat dijadikan sumber pendapatan karena kaya akan kandungan mineral dimana ternak kerbau dapat memproduksi susu mencapai 0,5-2,25 liter/ekor/hari pada kondisi pemeliharaan suboptimal. Kadar lemak dan protein susu kerbau lebih baik dari pada susu sapi, kaya akan kandungan mineral penting seperti $\mathrm{Ca}$, $\mathrm{Fe}$, dan $\mathrm{P}$, kandungan kolesterol lebih rendah, kandungan vitamin A lebih tinggi, artinya susu adalah makanana sehat karena mengandung bioprotective antara lain imunoglobulin, laktoferin, lisozim, laktoperoksidase, dan 
bifidogenik (Matondang, 2015).

Menurut Talib (2015) dibutuhkan suatu mekanisme agar kelompok peternak pembibit dapat menerapkan prinsip pembibitan untuk menghasilkan bibit kerbau unggul pada prinsipnya masyarakat yang beternak secara tradisional tanpa ada kandang utama dan tampa memperhatikan dengan baik ketersediaan kandang dan peralatannya, umumnya kondisi pemeliharaan kerbau terletak di daerah pegunungan yang jauh dari pemukiman penduduk, sehingga sangat rentan terhadap binatang buas pemangsa dan gangguan hewan liar lainnya (Sari, 2015).

Dalam pemeliharaan ternak secara tradisional banyak faktor yang menjadi masalah dalam pemeliharaan ternak Kerbau Gayo, seperti kurangnya pengontrolan pada ternak, belum menerapkan sistem recording, masih menggunakan kawin alam, tidak ada persedian pakan hijaun secara kontinu, terjadinya kematian mendadak pada ternak. Beberapa masalah lain seperti, dimakan binantang buas, tertimpa pohon, jatuh dari pekarangan, ternak hilang karen dicuri akibat ternak yang belum menggunakan kandang utama. Bahkan masih ada yang sama sekali tidak menggunakan kandang maupun Uwer. Sehingga yang menjadi tujuan penelitian ini yaitu untuk menganalisis aspek-aspek yang mempengaruhi dan strategi pengembangan ternak kerbau Gayo serta mengukur karakteristik peternak yang mempengaruhi faktor-faktor pengembangan peternakan kerbau di Kabupaten Aceh Tengah.

\section{MATERI DAN METODE}

Penelitian ini dilakukan di Kecamatan Linge Kabupaten Aceh Tengah Provinsi Aceh. Waktu penelitian mulai dari Bulan Januari Agustus 2020. Menggunakan metode survey. Lokasi dipilih secara purposive adalah kawasan yang memiliki populasi Kerbau Gayo tertinggi serta menjadi sentral peternakan di Kabupaten Aceh Tengah

Responden adalah 54 peternak yang ditentukan secara purposive dari peternak yang aktif memelihara ternak Gayo di Kecamatan Linge Kabupaten Aceh Tengah. Wawancara dilakukan dengan menggunakan daftar pertanyaan langsung kepada peternak Kerbau Gayo disamping pengamatan ke lokasi peternak untuk mengamati sistem budidaya yang diterapkan. Data yang dikumpulkan dalam penelitian ini berupa data primer dan data sekunder. Data primer diambil dari hasil wawancara di lapangan, karakteristik peternak, manajemen peternakan dan kendala yang dihadapi oleh peternak. Untuk memperoleh imformasi dan data penulis melakukan wawancara dengan peternak, dinas pertanian, penyuluh tenaga, tenaga kesehatan hewan, agen/moge serta masyarakat.

\section{Analisis data}

Analisis data yang digunakan untuk merumuskan sebuah strategy tentang sistem pengembangan ternak kerbau di Kecamatan Linge Kabupaten Aceh Tengah yaitu dengan perumusan strategi menggunakan analisis SWOT serta dianalisis secara deskriptif.

\section{HASIL DAN PEMBAHASAN}

\section{Karakteristik petani sampel}

Karakteristik peternak merupakan faktor penting dalam melakukan usaha peternakan sebab karakteristik sebagai pendorong meningkatkan keberhasilan perternak, semakin baik karakteristiknya semakin baik juga usaha yang ditekuninya. Karakteristik peternak juga sangatberhubungandengantingkatkemampuan untuk mengelola usahanya. Karakteristik yang diamati dalam penelitian ini yaitu umur, tingkat pendidikan, kepemilikan ternak, pengetahuan, dan tingkat motivasi beternak Kerbau Gayo di daerah penelitian (Tabel 1 dan 2).

Umur peternak di daerah penelitian masih tergolong produktif dimana persentase tertinggi terdapat pada umur 37-50 tahun artinya peternak masih tergolong sangat produktif dalam melakukan usaha peternakan di Kecamatan Linge Kabupaten Aceh Tengah seperti yang diutarakan oleh Sari (2019) usia peternak diatas 65 tahun sudah tidak produktif lagi dalam melakukan sebuah usaha peternakan.

Rata-rata tingkat pendidikan peternak kerbau di daerah penelitian yaitu berpendidikan SD yaitu sebanyak 50\%. Sedangkan berpendidikan tertinggi yaitu pendidikan tamatan Sarjana hanya $4 \%$ dari total jumlah peternak. Artinya dari tingkat pendidikan peternak di tingkat pendidikan masih tergolong sangat rendah. bahwa tingkat pendidikan peternak merupakan indikator kualitas penduduk dan merupakan peubah kunci dalam pengembangan sumberdaya manusia.

Menurut Mulyawati (2016) tingkat 
Tabel 1. Umur, pendidikan dan kepemilikan ternak pada pengembangan ternak kerbau Gayo di Kecamatan Linge Kabupaten Aceh Tengah.

\begin{tabular}{lcccccc}
\hline No. & $\begin{array}{c}\text { Umur } \\
(\text { Tahun })\end{array}$ & $\mathrm{N}(\%)$ & Pendidikan & $\mathrm{N}(\%)$ & $\begin{array}{c}\text { Kepemilikan } \\
\text { ternak (ekor) }\end{array}$ & $\mathrm{N}(\%)$ \\
\hline 1. & 23,36 & $12(22)$ & SD & $27(50)$ & $1-7$ & $27(50)$ \\
2. & 37,50 & $20(37)$ & SMP & $15(28)$ & $8-14$ & $17(31)$ \\
3. & 51,64 & $18(33)$ & SMA & $10(19)$ & $15-21$ & $6(11)$ \\
4. & $>65$ & $4(7)$ & Sarjana & $2(4)$ & $>22$ & $4(7)$ \\
\hline
\end{tabular}

pendidikan mempengaruhi peternak dalam adaptasi dan inovasi dalam beternak. Di daerah penelitian masyarakat yang berpendidikan lebih banyak fokus pada pekerjaan lain seperti wiraswasta maupun pegawai (ASN) kemudian ternak yang mereka miliki akan dititipkan pada peternak lain dengan sistem bagi hasil.

Kepemilikan ternak salah satu motivasi peternak dalam memelihara ternak Kerbau Gayo serta modal awal untuk mempertahankan usaha peternakan dari Tabel 1 dapat dilihat bahwa kepemilikan ternak tertinggi yaitu 1-7 ekor dari jumlah populasi ternak 1.075 ekor di daerah penelitian. Keberhasilan dalam pendapatan usaha beternak sangat dipengaruhi oleh skala usaha atau jumlah kepemilikan ternak oleh peternak itu sendiri. Skala usaha memberikan keuntungan pada peternak, semakin banyak ternak yang dimiliki peternak, makin besar keuntungan artinya tingkat kepemilikan ternak sangat berpengaruh kepada besar kecilnya pendapatan usaha Krisna (2014). Memilih memelihara ternak orang lain merupakan satu upaya yang harus dilakukan untuk mendapatkan modal awal beternak dan menambah pendapatan.

Dalam usaha peternakan manajemen merupakan segala aspek yang berhubungan dengan sistem manajemen pemeliharaan ternak, yaitu pengelolaan perkawinan, manajemen pemberian pakan, pemberian air minum, pemeriksaan kesehatan, pemeriksaan kebuntingan, sistem perkandangan, penanganan penyakit, pengontrolan dan recording.

Pengetahuan peternak terhadap manajemen peternakan yaitu masih tergolong rendah dimana persentase pengetahuan yaitu tertinggi pada persentase 17-18 pengetahuan dengan persentase $48 \%$ sedangkan pada jawaban tertinggi hanya terdapat $4 \%$ artinya pengetahuan peternak masih mengandalkan pengetahuan secara tradisional sehingga pengetahuan terhadap manajemen peternakan masih rendah. Masyarakat yang baru memulai memelihara ternak memperoleh pengetahuan berdasarkan pengalaman orang tua mereka, dan sebagian bertanya dan melihat langsung sistem berternak tetangganya yang memelihara ternak. Selain untuk manajemen pengetahuan, motivasi dan biaya IB memiliki pengaruh terhadap adopsi teknologi inseminasi buatan (Syatra, dkk., 2016).

Motivasi peternak didaerah masih tergolong sangat tinggi, karena peternakan merupakan sumber pendapatan keluarga serta menjadi status sosial dikalangan masyarakat. Demikian juga dengan harga yang terus meningkat sehingga dapat dilihat pada Table 2 persentase motivasi peternak sangat tinggi yaitu berada pada nilai tertinggi sebanyak 43 $\%$. Rahmat (2006) dalam Fuah and Purwanto, (2015) menyatakan bahwa dengan adanya motivasi untuk melakukan suatu kegiatan sangat menentukan apakah Kecamatan Linge kegiatanitu betul-betul dilakukan ataukah tidak. Motivasi peternak Kerbau Gayo di Kecamatan Linge salah satu faktor pendukung motivasi

Tabel 2. Pengetahuan dan motivasi peternak pada pengembangan ternak kerbau Gayo di Kecamatan Linge Kabupaten Aceh Tengah.

\begin{tabular}{lcccc}
\hline No. & Pengetahuan & $\mathrm{N}(\%)$ & Motivasi & $\mathrm{N}(\%)$ \\
\hline 1. & $15-16$ & $10(19)$ & $26-27$ & $3(6)$ \\
2. & $17-18$ & $26(48)$ & $28-29$ & $10(19)$ \\
3. & $19-20$ & $16(30)$ & $30-31$ & $18(33)$ \\
4. & $21-22$ & $2(4)$ & $32-34$ & $23(43)$ \\
\hline
\end{tabular}


yaitu kepemilikan ternak, tingkat harga, sistem pemasaran yang mudah, biaya yang murah, tingkat sosial yang tinggi, sistem pemeliharaan yang mudah serta dapat mencukupi kebutuhan keluargajikaada kebutuhan besar danmendesak maka ternak bisa menjadi andalan utama.

\section{Hasil evaluasi faktor internal}

Evaluasi faktor internal dilakukan dengan pencarian nilai rata-rata masing-masing faktor kunci internal yang selanjutnya disusun dalam sebuah matriks evaluasi masing-masing faktor. Pada matriks evaluasi tersebut, masingmasing faktor yaitu kekuatan dan kelemahan ditambahkan bobot masing-masing dengan menggunakan pembobotan, kemudian digunakan matriks Evaluasi IPAS (Faktor Internal)

Dari Tabel 3 dapat dijelaskan bahwa ternak kerbau dapat memproduksi daging, susu serta dapat digunakan sebagai ternak kerja. Selain rasa dagingnya lebih disukai oleh masyarakat ternak kerbau Gayo juga dapat dimanfaatkan sebagai ternak penghasil susu yang sudah dilakukan oleh masyarakat meskipun hanya sebatas konsumsi keluarga. Pada umumnya beberapa petani yang memiliki sawah, jaraknya berjauhan dari desa, masih menggunakan ternak kerbau Gayo untuk melumatkan sawahnya dengan sistem (Mungoro) dan (Munor) untuk bekerja Sari (2020) Saat ini masih banyak sawah yang tidak bisa dijangkau oleh teknologi pertanian seperti sawah, tentunya masyarakat akan memanfaatkan ternak kerbau untuk membantu sawahnya.

Kemudian yang menjadi kelemahan utama yaitu kurangnya pengontrolan pada ternak kerbau gayo, pengontrolan pada ternak kerbau sangat jarang dilakukan sehigga beberapa ternak menjadi liar maupun hilang. Dikecamatan linge rata-rata peternak mengontrol ternaknya kurang dari dua kali dalam seminggu, hanya beeberapa peternak yang mengontrol ternaknya setiap hari. Menurut Sari (2019) peternak di Kecamatan Linge Kabupaten Aceh Tengah melakukan pengontrolan disaat tertentu saja, jika peternak memiliki waktu luang.

Tabel 3. Hasil evaluasi perhitungan kekuatan dan kelemahan hasil evaluasi IPAS (Faktor Internal) pada pengembangan ternak kerbau Gayo di Kecamatan Linge Kabupaten Aceh Tengah.

\begin{tabular}{|c|c|c|c|c|}
\hline $\mathbf{A}$ & Kekuatan & Bobot & Peringkat & Skor \\
\hline 1. & Luasnya lahan kosong yang belum termanfaatkan & 0,055 & 4 & 0,221 \\
\hline 2. & $\begin{array}{l}\text { Ternak kerbau Gayo yang sudah lama dikembangkan } \\
\text { secara turun temurun }\end{array}$ & 0,067 & 4 & 0,267 \\
\hline 3. & Rasa daging lebih disukai dibandingkan ternak sapi & 0,048 & 3 & 0,145 \\
\hline 4. & Lebih jinak dan setia terhadap pemiliknya & 0,068 & 3 & 0,204 \\
\hline 5. & $\begin{array}{l}\text { Dalam sistem pemeliharaan penggunaan biaya sangat } \\
\text { rendah }\end{array}$ & 0,063 & 3 & 0,190 \\
\hline \multirow[t]{2}{*}{6.} & $\begin{array}{l}\text { Ternak kerbau dapat memproduksi daging, susu serta } \\
\text { dapat digunakan sebagai ternak kerja }\end{array}$ & 0,068 & 4 & 0,272 \\
\hline & Sub total & 0,370 & & 1,299 \\
\hline B & Kelemahan & & & \\
\hline 1. & $\begin{array}{l}\text { Manajemen pemeliharaan peternak masih bersipat } \\
\text { tradisional }\end{array}$ & 0,0696 & 3 & 0,209 \\
\hline 2. & $\begin{array}{l}\text { Kurangnya pengetahuan dan pemahaman peternak } \\
\text { mengenai manajemen pemeliharan ternak }\end{array}$ & 0,0693 & 3 & 0,208 \\
\hline 3. & Kurangnya perncatatan ternak (Rekording) & 0,0456 & 3 & 0,137 \\
\hline 4. & Kurangnya penanganan kesehatan & 0,0508 & 3 & 0,152 \\
\hline 5. & $\begin{array}{l}\text { Tidak ada pemberian pakan tambahan selain pakan } \\
\text { yang didapatkan oleh ternak }\end{array}$ & 0,0706 & 4 & 0,283 \\
\hline 6. & Belum menerapkan sistem IB & 0,0569 & 4 & 0,228 \\
\hline \multirow[t]{3}{*}{7.} & Kurangnya pengontrolan pada ternak & 0,0720 & 4 & 0,288 \\
\hline & Subtotal & 0,435 & & 1,504 \\
\hline & Total & 0,805 & & 2,803 \\
\hline
\end{tabular}




\section{Hasil evaluasi faktor eksternal}

Evaluasi faktor-faktor eksternal merupakan langkah untuk merencanakan dan mengarahkan tindakan yang akan diambil perusahaan/ organisasi berdasarkan perkembangan faktor eksternal yang mempengaruhi. Teknik penentuan respons yang dilakukan adalah dengan cara pemberian bobot dan pemberian peringkat serta menyusun matriks Evaluasi peluang dan Ancaman EPAS (Faktor Eksternal). Hasil analisis EPAS dapat dilihat pada Tabel 4.

Tabel 4 dapat dijelaskan bahwa peluang utama dalam pengembangan ternak kerbau Gayo sistem tradisional di Kecamatan Linge Kabupaten Aceh Tengah yaitu adanya peluang pasar maupun ekspor. Untuk saat ini peternak masih menjual ternaknya secara langsung pada agen yang sudah berlangganan.

Setiap agen merasa kewalahan dan harus bekerja keras untuk mendapatkan satu ekor ternak, hal ini diakibatkan kebutuhan ternak masih belum mencukupi khususnya dikabupaten Aceh Tengah. Peluang ini yang menjadi salah satu alasan harga ternak kerbau Gayo yang tidak pernah turun di tingkat pasar.

Selainitusebuahancamanyangharussegera dihindari dan menemukan sebuah solusinya yaitu alih fungsi lahan yang saat ini masih luas sihingga masih banyak lokasi yang dapat digunakan sebagai lokasi pengembalaan sistem peruweren oleh peternak. Dengan menerapkan sistem pemeliharaan yang intensif serta adanya peran pemerintah dalam menetapkan lokasi peruweren melalui peraturan pemerintah/ Qanun.

Di kabupaten Bener Meriah hal ini sudah pernah dilakukan dengan menetapkan lokasi Peruweren yaitu sebuah lokasi peternakan tempat masyarakat adat untuk melaksanakan aktifitas peternakan/penggembalaan hewan ternak baik intuk ternak kerbau Gayo maupun sapi Bali (Gayo, 2018).

Tabel 4. Hasil Evaluasi Peluang dan Ancaman EPAS (Faktor Eksternal) pada pengembangan ternak kerbau Gayo di Kecamatan Linge Kabupten Aceh Tengah.

\begin{tabular}{|c|c|c|c|c|}
\hline A & Peluang & Bobot & Peringkat & Skor \\
\hline 1. & $\begin{array}{l}\text { Daya dukung sumber daya alam seperti limbah hasil } \\
\text { pertanian yang dapat dijadikan sebagai pakan olahan } \\
\text { ternak kerbau Gayo }\end{array}$ & 0,047 & 3 & 0,141 \\
\hline 2. & $\begin{array}{l}\text { Meningkatnya kebutuhan daging seiring pertambahan } \\
\text { penduduk }\end{array}$ & 0,078 & 3 & 0,231 \\
\hline 3. & $\begin{array}{l}\text { Meningkatnya perkembangan teknologi serta sistem } \\
\text { informasi }\end{array}$ & 0,050 & 3 & 0,151 \\
\hline 4. & $\begin{array}{l}\text { Adanya dukungan pemerintah pusat dan pemerintah } \\
\text { daerah tentang pengembangan peternakan }\end{array}$ & 0,046 & 4 & 0,182 \\
\hline 5. & Program IB pada kerbau bisa dilaksanakan & 0,062 & 3 & 0,187 \\
\hline \multirow[t]{2}{*}{6.} & Adanya peluang pasar baik lokal maupun ekspor & 0,068 & 4 & 0,272 \\
\hline & Sub total & 0,352 & & 1,165 \\
\hline B & Kelemahan & & & \\
\hline 1. & $\begin{array}{l}\text { Manajemen pemeliharaan peternak masih bersipat } \\
\text { tradisional }\end{array}$ & 0,0641 & 3 & 0,192 \\
\hline 2. & $\begin{array}{l}\text { Kurangnya pengetahuan dan pemahaman peternak } \\
\text { mengenai manajemen pemeliharan ternak }\end{array}$ & 0,0689 & 3 & 0,207 \\
\hline 3. & Kurangnya perncatatan ternak (Rekording) & 0,0621 & 3 & 0,186 \\
\hline 4. & Kurangnya penanganan kesehatan & 0,0590 & 3 & 0,177 \\
\hline 5. & $\begin{array}{l}\text { Tidak ada pemberian pakan tambahan selain pakan } \\
\text { yang didapatkan oleh ternak }\end{array}$ & 0,0583 & 4 & 0,233 \\
\hline 6. & Belum menerapkan sistem IB & 0,0614 & 3 & 0,184 \\
\hline \multirow[t]{3}{*}{7.} & Kurangnya pengontrolan pada ternak & 0,0720 & 4 & 0,288 \\
\hline & Subtotal & 0,432 & & 1,415 \\
\hline & Total & 0,784 & & 2,580 \\
\hline
\end{tabular}


Tabel 5. Matriks SWOT Strategi Pengembangan Ternak Kerbau Gayo di Kabupaten Aceh Tengah

\begin{tabular}{|c|c|c|}
\hline & Kekuatan (S) & Kelemahan (W) \\
\hline EPAS & 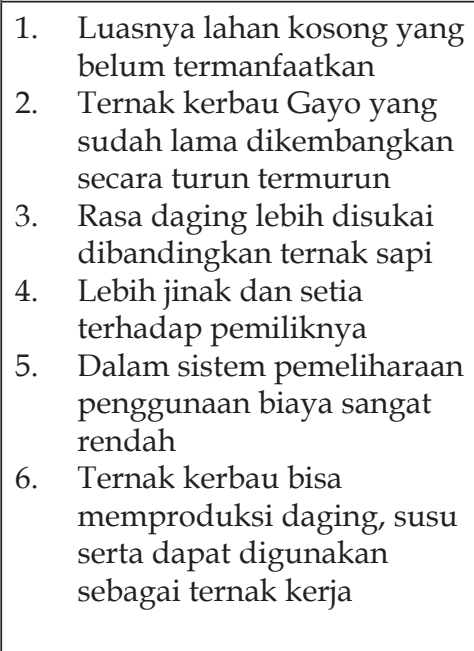 & 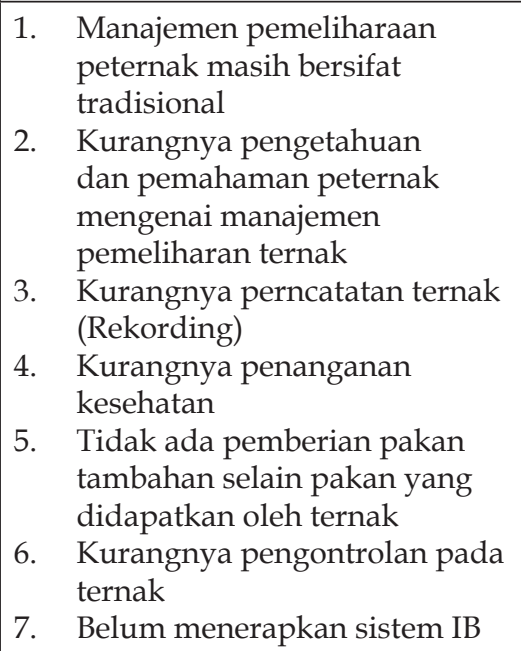 \\
\hline Peluang (O) & STRATEGI SO & STRATEGI WO \\
\hline $\begin{array}{ll}\text { 1. } & \text { Daya dukung sumber daya alam } \\
\text { seperti limbah hasil pertanian } \\
\text { yang dapat dijadikan sebagai } \\
\text { pakan olahan ternak kerbau Gayo } \\
\text { 2. Meningkatnya kebutuhan daging } \\
\text { seiring pertambahan penduduk } \\
\text { 3. Meningkatnya perkembangan } \\
\text { teknologi serta sistem informasi } \\
\text { 4. Adanya dukungan pemerintah } \\
\text { pusat dan pemerintah daerah } \\
\text { tentang pengembangan } \\
\text { peternakan } \\
\text { 5. Adanya peluang pasar baik lokal } \\
\text { maupun ekspor } \\
\text { 6. Program IB pada kerbau bisa } \\
\text { dilaksanakan }\end{array}$ & $\begin{array}{l}\text { Memanfaatkan lahan kosong } \\
\text { untuk dijadikan sumber } \\
\text { pakan dan pakan olahan } \\
\text { serta meningkatkan populasi } \\
\text { dan produksi ternak melalui } \\
\text { perbaikan manajemen } \\
\text { pemeliharaan, pakan, dan } \\
\text { kesehatan dengan menerapkan } \\
\text { sistem IB, (Mengelola S1, S2, } \\
\text { S3, S4, S5 dan Memanfaatkan } \\
\text { O1,O2,O3,O4 dan O5) }\end{array}$ & $\begin{array}{l}\text { Meningkatkan pengetahuan } \\
\text { peternak terhadap manajemen } \\
\text { kesehatan hewan, penyuluhan, } \\
\text { sosialisasi manfaat kawin } \\
\text { IB, pembuatan pakan olahan, } \\
\text { penanaman HMT serta pembinaan } \\
\text { kepada tenaga ahli IB dan peternak. } \\
\text { (Memanfaatkan O1,O2,O3,O4, O5 } \\
\text { meminimalkan W1,W2,W3,W4 dan } \\
\text { W5) }\end{array}$ \\
\hline Ancaman (T) & STRATEGI ST & STRATEGI WT \\
\hline $\begin{array}{ll}\text { 1. Skala usaha dan akses peternak } \\
\text { terhadap lembaga permodalan } \\
\text { masih rendah }\end{array}$ & $\begin{array}{l}\text { Bermitra dengan lembaga } \\
\text { pemodalan serta dukungan } \\
\text { pemerintah, memperkuat } \\
\text { regulasi terhadap lahan } \\
\text { peternakan, dan jual beli ternak } \\
\text { serta menciptakan peternakan } \\
\text { dengan pemeliharaan sistem } \\
\text { intensif sebagai ternak } \\
\text { percontohan di Kabupaten } \\
\text { Aceh Tengah dengan sistem IB } \\
\text { serta memperkuat penanganan } \\
\text { kesehan dan menekan angka } \\
\text { kematian pada ternak, } \\
\text { (Mengelola, S1, S2, S3, S4, S5 } \\
\text { mengatasi T1, T2, T3, T4 dan T5) }\end{array}$ & $\begin{array}{l}\text { Melakukan pembinaan peternak } \\
\text { dan pelatihan manajemen pakan, } \\
\text { perkandangan, penanganan } \\
\text { penyakit, pencatatan, pengontrolan } \\
\text { serta penyediaan sarana dan } \\
\text { prasarana pembibitan pemurnian } \\
\text { plasma nutfah dan penerapan IB } \\
\text { untuk ternak. Meminimalkan W1, } \\
\text { W2, W3, W4, W5 Menghindari T, } \\
\text { T2, T3, T4 Dan T5) }\end{array}$ \\
\hline
\end{tabular}


Dari hasil evaluasi faktor internal dan faktor internal untuk mendapatkan grand strategy yang dapat menjadikan sebuah solusi perlu dianalisis menggunakan matrik Matriks SWOT Strategi Pengembangan Ternak Kerbau Gayo di Kabupaten Aceh Tengah.

Hasil analisis penggabungan faktor internal dan ekternal melalui matriks SWOT (Tabel 5), maka alternatif-alternatif strategi pengembangan ternak kerbau Gayo diperoleh adalah; strategi SO (Strengths-Opportunities); strategi ST (Strengths-Threats); strategi WO (Weaknesses-Opportunities); dan strategi WT (Weaknesses-Threats). Dari keempat strategi ditentukan sebuah strategi terbaik yang akan digunakan untuk mengatasi permasalahan pada pengembangan ternak kerbau Gayo. Dikecamatan Linge Kabupaten Aceh Tengah. Adapun analisis yang digunakan yaitu analisis grand strategy. Untuk melihat grand strategy dapat dilihat pada Gambar 1.

Berdasarkan Gambar 1, strategi peternakan Kerbau Gayo di Kabupaten Aceh Tengah berada pada kuadran Agresif. Dimana terletak pada titik potong garis antara total faktor internal 2.803 dan faktor eksternal 2.580. Pada kuadran agresif (Strategi SO) ini, merupakan keadaan yang sangat menguntungkan bagi peternakan Kerbau Gayo di Kabupaten Aceh Tengah. Daerah ini memiliki peluang yang sangat baik sehingga dapat memanfaatkan untuk pengembangan peternakan Kerbau Gayo. Oleh sebab itu, strategi yang diterapkan dalam kondisi ini adalah mendukung kebijakan pertumbuhan agresif (Growth Oriented Strategy) yaitu memanfaatkan lahan kosong untuk dijadikan sumber pakan dan pakan olahan serta meningkatkan populasi dan produksi ternak melalui perbaikan manajemen pemeliharaan, pakan, dan kesehatan dengan menerapkan sistem Inseminasi Buatan"

\section{KESIMPULAN DAN SARAN}

\section{Kesimpulan}

Karakteristik peternak di Kecamatan Linge yaitu pendidikan, kepemilikan ternak dan pengetahuan peternak masih sangat rendah. Sedangkan untuk umur masih sangat produktif dan memiliki motivasi yang tinggi dalam memelihara ternak kerbau Gayo di Kecamatan Linge Kabupaten Aceh Tengah.

Berdasarkan hasil grand strategy pengembangan ternak kerbau Gayo, maka diperoleh strategi Agresif yaitu menggunakan kekuatan dengan memanfaatkan lahan kosong untuk dijadikan sumber pakan serta pakan olahan dari hasil pertanian, meningkatkan populasi ternak kerbau Gayo dan produksi ternak melalui perbaikan aspek manajemen pemeliharaan, aspek pakan ternak kerbau, dan kesehatan dengan menerapkan sistem inseminasi buatan pada ternak Kerbau Gayo di Kecamatan Linge Kabupaten Aceh Tengah

\section{Saran}

Pengembangan ternak Kerbau Gayo perlu di pertahankan dan terus dikembangkan dengan memperbaiki aspek pemeliharaan, aspek pakan, penanganan kesehatan serta menambah pengetahuan peternak melalui pelatihan khusus untuk peternak. Perlunya peran pemerintah dalam menetapkan lokasi pemeliharaan (peruweren) untuk ternak Kerbau Gayo melalui Qanun atau Peraturan Dikabupaten Aceh Tengah.

\section{UCAPAN TERIMA KASIH}

Lembaga Penjaminan Mutu Internal Universitas Gajah Putih, dan Direktorat

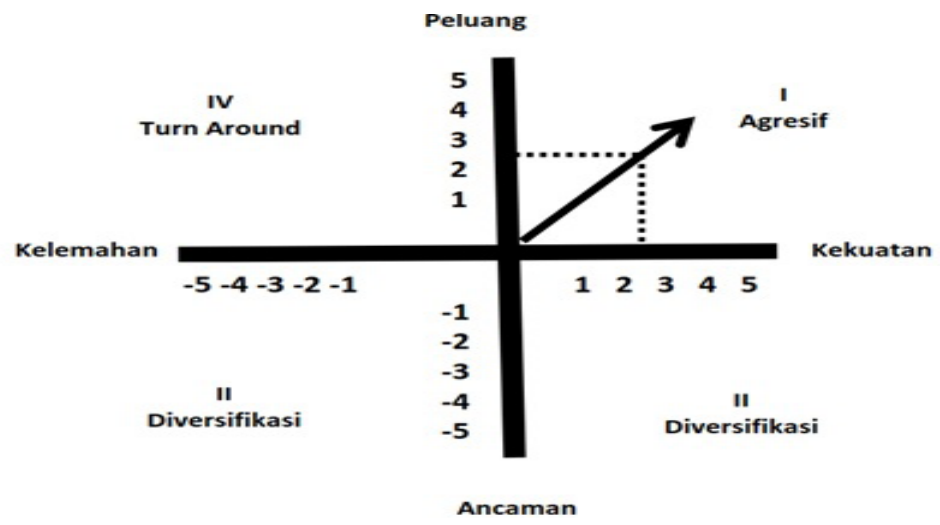

Gambar 1. Strategi Pengembangan Ternak Kerbau Gayo Terhadap Pemeliharaan Ternak Kerbau Gayo di Kecamatan Linge Kabupaten Aceh Tengah. 
Jenderal Penguatan Riset dan Pengembangan Kementerian Riset, Teknologi, dan Pendidikan Tinggi.

\section{DAFTAR PUSTAKA}

Badan Pusat Statistik. 2020. Kabupaten Aceh Tengah Dalam Angka in Tengah, Buku Statistik Kabupaten Aceh.

Fuah, A. M. dan B. P. Purwanto. 2015. Motivasi dan partisipasi peternak dalam pengembangan ternak kerbau diKabupaten Pandeglang (Studi Kasus : Desa Cibarani Kecamatan Cisata). Journal Sains, 5(1): 1-7.

Gayo, A. A. 2018. Perlindungan hukum hak atas tanah adat (Studi Kasus di Provinsi Aceh Khususnya Kabupaten Bener Meriah). De Jure Jurnal penelitian Hukum, 18(3): 15.

Ikun, A. 2018. Faktor-faktoryang mempengaruhi tingkat populasi ternak kerbau di Kecamatan Biboki Anleu Kabupaten Timor Tengah Utara. JAS, 3(3): 38-42.

Krisna, Rizal, H. 2014. Hubungan tingkat kepemilikan dan biaya usaha dengan pendapatan peternak sapi potong di Kabupaten Sukabumi Provinsi Jawa Barat (Studi Korelasi). Aplikasi Manajemen, 12(2): 295-305.

Matondang, R. H. dan C. Talib. 2015. Pemanfaatan ternak kerbau untuk mendukung peningkatan produksi susu. Jurnal Penelitian dan Pengembangan Pertanian, 34(1): 41-49.

Mulyawati, I. M., Mardiningsih dan S. Satmoko. 2016 Pengaruh umur, pendidikan, pengalaman dan jumlah ternak peternak kambing terhadap perilaku sapta usaha beternak kambing di Desa Wonosari, Kecamatan Patebon. Agromedia, 34(1): 85-90.
Par, A. U. H. 2018. Pemanfaatan recording untuk meningkatkan manajemen ternak kerbau di Kecamatan Matawai La Pawu Kabupaten Sumba Timur. Jurnal Sain Peternakan Indonesia, 13(1): 101-110.

Rusdiana, S. dan I. Herdiawan, 2017. Pengetahuan peternak dananalisis ekonomi penggunaan rumput Chloris gayana sebagai pakan kerbau di lahan penggembalaan. Buletin Peternakan, 41(2): 219.

Sari, E. M., M. A. N. Abdullah dan S. Sulaiman. 2015. Kajian aspek teknis pemeliharaan kerbau lokal di Kabupaten Gayo Lues. Jurnal Agripet, 15(1): 57-60.

Sari, E. 2020. Sumber Daya Genetik Ternak Lokal Kerbau Gayo. Syiah Kuala University Press, Banda Aceh.

Sari, E. M., W. Aramicorindi, and M. A. Abdullah. 2019. Reproduction characteristics of Gayo Buffalo in Wih Pesam District of Bener Meriah Regency. In International Seminar on Tropical Animal Production (ISTAP). pp. 48-51.

Syatra, U., Kasim, S. N. dan Asnawi, A. 2016. Pengaruh Pengetahuan, Motivasi dan Biaya Ensiminasi. Jurnal Ilmu dan Industri Peternakan, 3(2): 71-76.

Yurleni, R. P., E. Gunardi, dan K. G. Wiryawan. 2013. Efektivitas minyak ikan Lemuru terproteksi terhadap populasi mikrob rumen dan fermentasinya pada kerbau dan sapi. Jurnal Verteriner, 14(3): 285-293. 